\title{
Retention of fluoride from diets containing materials produced during aluminium smelting
}

\author{
BY D. A. WRIGHT \\ Department of Zoology, University of Newcastle upon Tyne, \\ Newcastle upon Tyne NEI $7 R U$ \\ AND A. THOMPSON \\ Department of Agricultural Biochemistry, University of Newcastle upon Tyne, \\ Newcastle upon Tyne NEI $7 R U$
}

(Received 26 May 1977 - Accepted 7 October 1977)

I. Using male rats, the availability of fluoride from five by products of the aluminium smelting industry was tested. This was done by considering the balance between fluoride administered in controlled diets and the total fluoride content of waste products eliminated over an experimental period of I week.

2. Results indicated that yields of available fluoride expressed as percentage weight of original material were cryolite $\left(\mathrm{Na}_{3} \mathrm{ALF} \mathrm{B}_{\mathrm{B}}\right), 45.9 \%$; sodium fluoride $(\mathrm{NaF}), 41 \cdot 7 \%$; aluminium fluoride $\left(\mathrm{ALF} \mathrm{F}_{3} . \mathrm{H}_{2} \mathrm{O}\right), 9 \cdot 1 \%$; mist eliminator grid solids (with $\mathrm{CaF}_{2}$ ), $9.4 \%$; reclaimed alumina with adsorbed $\mathrm{F}, 0.27 \%$.

3. Of the various tissues analysed for fluoride content, only the kidney and femur showed any significant correlation with the amounts of fluoride absorbed or retained.

With the expansion of heavy industries into previously rural areas, fluorosis in livestock continues to give rise to occasional problems. The aetiology and prophylactic treatments have been well reviewed by a number of authors (Burns \& Allcroft, I964; National Academy of Sciences, 1971 ; Shupe, 1970; Suttie, 1964, 1967, 1969). Field experiments in which soluble sodium fluoride (NaF) has been administered to dairy and beef cattle have been reviewed by Shupe (1970) and Suttie, Phillips \& Miller (1958) and Suttie, Carlson \& Faltin (1972).

Less is known, however, about the availability to the animal of the various less-soluble dusts which are found closer to the industrial complexes. Indeed, the exact chemical nature of some of these dusts is not known with certainty and the dusts themselves may, in fact, be mixtures. The industrial processes most implicated in the production of such dusts include the manufacture of phosphate fertilizers, aluminium and steel smelting and, to a lesser extent, the firing of brick and ceramic materials. In close proximity to aluminium smelters, particulate fluorides may sometimes constitute half of the total atmospheric fluoride load, the remainder being largely the gaseous hydrogen fluoride (HF) fraction.

In the present work, five types of fluoride-rich dusts found in and around an aluminium smelter were tested for the availability of the fluoride to experimental rats, using a fluoridebalance procedure.

\section{MATERIALS AND METHODS}

\section{Materials}

The following dusts were obtained from Alcan (UK) Ltd. (I) Cryolite; $\mathrm{Na}_{3} \mathrm{AlF}_{6}$ molten cryolite is the electrolyte used in the electrolytic reduction of alumina. (2) Aluminium fluoride $\left(\mathrm{AlF}_{3}\right)$ is added to the cell during the electrolytic process. (3) Sodium fluoride (NaF). As is common practice, NaF is used here as a reference standard against which the other materials are compared. (4) Reclaimed alumina. Fluoride emissions from the electrolytic cells can be cleaned by wet or dry scrubbing. In a dry scrubbing plant, gases from the cells 
Table I. Composition of the semi-synthetic basal diet $(\mathrm{g} / \mathrm{kg}$ diet $)$

$\begin{array}{lr}\text { Maize starch } & 550 \\ \text { Glucose } & 160 \\ \text { Cellulose } & 80 \\ \text { Maize oil } & 100 \\ \text { Complete vitamin mix } & 20 \\ \text { Complete mineral mix } \dagger & 10\end{array}$

* The vitamin mix supplied/kg diet: Vitamin A (200000 IV/g) $90 \mathrm{mg}$; cholecalciferol (400000 IU/g) $5 \mathrm{mg}$; $\alpha$-tocopherol $100 \mathrm{mg}$; ascorbic acid $900 \mathrm{mg}$; inositol $100 \mathrm{mg}$; choline chloridel $5 \mathrm{~g}$; $p$-aminobenzoic acid $100 \mathrm{mg}$; niacin $90 \mathrm{mg}$; riboflavin $20 \mathrm{mg}$; pyridoxine hydrochloride $20 \mathrm{mg}$; thiamin hydrochloride $20 \mathrm{mg}$; calcium pantothenate $60 \mathrm{mg}$; biotin $400 \mathrm{mg}$; folic acid $\mathrm{I} .8 \mathrm{mg}$; cyanocobalamin $27 \mathrm{mg}$.

$\dagger$ The mineral mix supplied/kg of diet: $\mathrm{CaCO}_{3} 6.7 \mathrm{~g} ; \mathrm{KH}_{2} \mathrm{PO}_{4} \mathrm{II} \cdot 7 \mathrm{~g} ; \mathrm{KCl} 3.3 \mathrm{~g} ; \mathrm{NaCl} 5.0 \mathrm{~g} ; \mathrm{MgSO}_{4}$. ${ }_{7} \mathrm{H}_{2} \mathrm{O} 2 \cdot \mathrm{I} \mathrm{g} ; \mathrm{FeSO}_{4} .7 \mathrm{H}_{2} \mathrm{O} 167 \mathrm{mg} ; \mathrm{CuSO}_{4} .5 \mathrm{H}_{2} \mathrm{O} 33 \mathrm{mg} ; \mathrm{MnSO}_{4} \cdot 4 \mathrm{H}_{2} \mathrm{O} 33 \mathrm{mg} ; \mathrm{Zn} \mathrm{SO}_{4} \cdot 7 \mathrm{H}_{2} \mathrm{O} 33 \mathrm{mg} ; \mathrm{KIO}_{3}$ $0.4 \mathrm{mg}$.

\section{Table 2. Fluorine composition of experimental diets}

Diet

(I) Basal

(2) Sodium fluoride (NaF) $70 \mathrm{~g} / \mathrm{kg}$ nominal

(3) Sodium fluoride $(\mathrm{NaF})$ $140 \mathrm{~g} / \mathrm{kg}$ nominal

(4) Aluminium fluoride $\left(\mathrm{AlF}_{3} \cdot \mathrm{H}_{2} \mathrm{O}\right)$

(5) Mist eliminator grid solids

(6) Cryolite $\left(\mathrm{Na}_{3} \mathrm{AlF}_{8}\right)$

(7) Reclaimed alumina
Fluorine composition of supplement (\%)

$-\overline{42 \cdot 5}$
$42 \cdot 5$
57
II $\cdot 3$
54
$0 \cdot 53$

Supplement incor- Dietary fluorine poration ( $\mathrm{g}$ added concentration to $\mathrm{kg}$ of basal diet $) \quad(\mathrm{g} / \mathrm{kg})$

* In view of the very high level of incorporation required, the supplement was added to $962 \cdot 3 \mathrm{~g}$ of basal diet rather than to the $\mathrm{kg}$ used in the other diets.

are treated with alumina. Fluoride from the effluent is adsorbed on to this alumina which is recycled to the cells for reduction. (5) Mist eliminator grid solids (MEG solids). This term covers an ill-defined complex resulting from particulate material which passes through a wet-scrubbing system and is collected on a mist eliminator grid. Where sea water is used in the scrubber, large amounts of inorganic salts derived from the sea water itself may also be present.

\section{Animals and housing}

Forty-two male albino rats, $50 \mathrm{~d}$ old (seven litter mates from six litters) of mean weight $\mathrm{I} 40 \mathrm{~g}$ were used. The seven litter mates from each of the six litters were randomly allocated to the seven diets. The animals were housed throughout the experiment in individual metabolism cages which provide for the separate collection of urine and faeces; these cages have been fully detailed by Thompson (1970).

\section{Diets}

Each rat was offered $9 \mathrm{~g} / \mathrm{d}$ of one of seven experimental diets for a $7 \mathrm{~d}$ preliminary and a $7 \mathrm{~d}$ experimental period. Details of the composition of the basal diet is given in Table $\mathrm{I}$, while Table 2 shows the amounts of the various fluoride sources added to prepare each of the seven experimental diets.

It had been the intention that, with the exception of the nominal $70 \mathrm{gF} / \mathrm{kg}$ and $140 \mathrm{gF} / \mathrm{kg}$ as $\mathrm{NaF}$, all the other supplemented diets should contain approximately the same amounts of fluoride. Table 2 also gives the determined fluoride contents of the final diets as fed and shows that reasonably uniform levels of $F$ had been achieved with the notable exception of diet 5 
containing the MEG solids which proved to have at least twice the fluoride content of the supplemented diets $3,4,6$ and 7 .

It can only be assumed that, as the MEG solids are probably the most heterogeneous of all the materials tested, the preliminary analysis of this material did not reflect accurately the sample of material actually used in compounding this diet.

\section{Experimental procedure}

The animals were starved for approximately $\mathrm{I} 2 \mathrm{~h}$ before the start of the experiment. After being weighed and allocated to their respective diets, the animals were placed in the individual metabolism cages for a preliminary period of $7 \mathrm{~d}$ to accustom them to the cages and the diets. Feed was offered once per day while distilled water was available ad lib. At the end of the preliminary period, the animals were reweighed and returned to their respective cages which were now fitted with urine and faeces separators; this marked the beginning of the $7 \mathrm{~d}$ faeces and urine collection period. All animals were offered $9 \mathrm{~g}$ diet/d which the majority of animals consumed completely. However, records of feed refusals show that one animal, receiving the higher level of $\mathrm{NaF}$, refused about $30 \%$ of offered diet, whilst all the animals receiving the MEG solids refused food to some extent; on average this group refused about $14 \%$ of offered diet.

At the end of the balance period the animals were weighed, killed and then deep frozen pending dissection.

\section{Preparation of samples for analysis}

Feed. Representative samples of each diet were collected throughout the balance period and bulked for analysis.

Urine. The total urine over the $7 \mathrm{~d}$ period was collected in flasks $10 \mathrm{ml}$ of $10 \% \mathrm{HCl}$ added and made up to $250 \mathrm{ml}$.

Faeces. The total faeces of each animal were collected over the $7 \mathrm{~d}$ period.

Tissues and organs. The kidney and left femur were dissected, washed with distilled water, dried at $100^{\circ}$ and their fluoride content determined.

\section{Analytical methods}

Feed and faeces samples were subjected to a dry-matter determination by drying in an oven at $105^{\circ}$ for $24 \mathrm{~h}$. Experimental diets, faeces and tissues were analysed for fluoride content using an Orion specific-ion electrode following alkaline fusion (Wright \& Davison, 1975).

The fluoride content of the urine samples was determined using the specific ion electrode on a solution containing urine $-0.25 \mathrm{M}-\mathrm{H}_{2} \mathrm{SO}_{4}$ - trisodium citrate/potassium nitrate buffer ( I : I : 3, by vol.) (Cooke, Johnson, Davison \& Bradshaw, I976). The fluoride content of the urine samples was also determined using the specific ion electrode on a solution containing urine - $0.5 \mathrm{M}$-perchloric acid $(\mathrm{I}: \mathrm{I}, \mathrm{v} / \mathrm{v})$ which is placed in a boiling water-bath for $\mathrm{I} 5 \mathrm{~min}$ and then cooled; the cooled solution is then mixed with 3 parts of trisodium citrate/ potassium nitrate buffer (Cernik, Cooke \& Hall, 1970). As the results from the two methods were virtually identical, mean values for the fluoride content of the urine samples are used throughout this report.

\section{Statistical analysis}

Where relevant the mean standard errors are shown whilst the more important parameters have been subjected to an analysis of variance. To enable this analysis to be carried out, it was necessary to employ the 'missing plot' technique of Steel \& Torrie (I960) due to the death of one rat referred to later. The multiple range procedure of Duncan (I955) was used in assessing the significance between treatments. 
Table 3. Mean intake, excretion, absorption and retention of fluoride in rats given diets supplemented with different sources of fluoride $(\mathrm{mg} / 7 \mathrm{~d})$

\begin{tabular}{|c|c|c|c|c|c|}
\hline Diet & Intake & $\begin{array}{c}\text { Faecal } \\
\text { excretion }\end{array}$ & $\begin{array}{l}\text { Apparent } \\
\text { absorbed }\end{array}$ & $\begin{array}{l}\text { Urinary } \\
\text { excretion }\end{array}$ & Retained \\
\hline & O. I I & - & - & - & - \\
\hline $\begin{array}{l}\text { ominal) } \mathrm{NaF} / \mathrm{kg} \\
\text { nominal) } \mathrm{NaF} / \mathrm{kg}\end{array}$ & $\begin{array}{l}4 \cdot 05 \\
7 \cdot 23\end{array}$ & $\begin{array}{l}0.12^{a} \\
0.06^{a}\end{array}$ & $\begin{array}{l}3 \cdot 93^{b} \\
7 \cdot 8^{d}\end{array}$ & $\begin{array}{l}2 \cdot 20^{b} \\
2 \cdot 48^{b}\end{array}$ & $1 \cdot 73^{a}$ \\
\hline $\mathrm{L}_{2} \mathrm{O}$ & $\begin{array}{r}10.43 \\
10.43\end{array}$ & $8 \cdot 77^{e}$ & $\begin{array}{l}7.66^{a} \\
\mathrm{a}\end{array}$ & $\begin{array}{l}3.40^{\circ} \\
0 \cdot 14^{a}\end{array}$ & $1 \cdot 52^{a}$ \\
\hline iminator solids & $19 \cdot 83$ & $3 \cdot 32^{c}$ & $16.52^{e}$ & $10 \cdot 35^{c}$ & $6 \cdot 17^{\mathfrak{c}}$ \\
\hline & $8 \cdot 70$ & $I \cdot 30^{b}$ & $7 \cdot 40^{d}$ & $2 \cdot 64^{b}$ & $4 \cdot 75^{b c}$ \\
\hline ned alumina & $11 \cdot 60$ & $5 \cdot 53^{d}$ & $6.07^{c}$ & $2 \cdot 04^{b}$ & $4 \cdot 04^{b}$ \\
\hline nean & - & 0.272 & 0.792 & 0.606 & $0 \cdot 368$ \\
\hline
\end{tabular}

The difference between any two means of the stated factor which do not carry the same superscript is significant $(P<0.05)$.
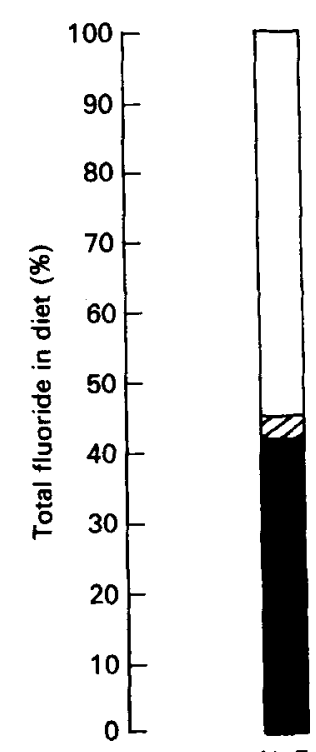

$(71 \mathrm{~g} / \mathrm{kg})$
(I) Basal

(2) $70 \mathrm{~g}$ (nominal) $\mathrm{NaF} / \mathrm{kg}$

(3) I $40 \mathrm{~g}$ (nominal) $\mathrm{NaF} / \mathrm{kg}$

(4) $\mathrm{AlF}_{3} \cdot \mathrm{H}_{2} \mathrm{O}$

(6) Cryolite

(7) Reclaimed alumina

SE of mean

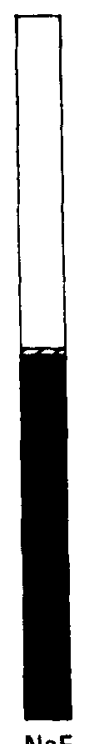

NaF
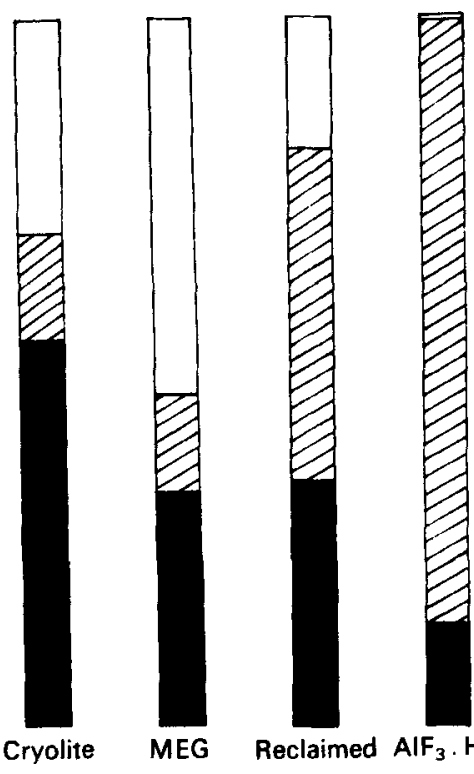

Reclaimed $\mathrm{AlF}_{3} \cdot \mathrm{H}_{2} \mathrm{O}$

solids alumina

Fig. I. Partition of dietary fluoride from experimental diets between the body, the faeces and the urine in rats over a 7 -d period. $\square$, Urine; $\square$, faeces; $\square$, retained fraction. MEG solids represent mist eliminator grid solids.

\section{RESULTS AND DISCUSSION}

While little significance can be attached to live-weight changes over such a short period of time, it is notable that all but two animals gained in weight during the experiment; these gains ranged from 4 to $17 \mathrm{~g}$ over the $7 \mathrm{~d}$ period. The variation in gain was random and was not associated with any particular diet. The two rats which lost in weight (I I and $28 \mathrm{~g}$, respectively) were both being given the diet containing $138 \mathrm{gF} / \mathrm{kg}$ as $\mathrm{NaF}$; however, the other four animals on this diet all gained in weight, one to the extent of $17 \mathrm{~g}$. It was noted during the trial that the two animals which lost weight drank large amounts of water and consumed slightly less diet than did the other rats on the same diet.

One animal died early in the preliminary period. This animal was receiving the diet containing $7 \mathrm{I} \mathrm{gF} / \mathrm{kg}$ as $\mathrm{NaF}$ but it is very unlikely that fluorine toxicity was the cause of 
Table 4. The mean percentage absorbed fluoride of intake (apparent availability \%) and the \% retained fluoride of absorbed in rats given diets supplemented with different sources of fluoride

\section{Diet}

$70 \mathrm{~g}$ (nominal) $\mathrm{NaF} / \mathrm{kg}$
$\mathrm{I} 40 \mathrm{~g}$ (nominal) $\mathrm{NaF} / \mathrm{kg}$
$\mathrm{AlF}_{3} \cdot \mathrm{H}_{2} \mathrm{O}$
Mist elminator grid solids
Cryolite
Reclaimed alumina
$\quad$ SE of mean

Absorbed F/intake F (apparent availability)* Retained $\mathrm{F} /$ absorbed $\mathrm{F}$

$(\%)$
$97 \cdot 2^{d}$
$99 \cdot 2^{d}$
$15 \cdot 9^{a}$
$83 \cdot 4^{d}$
$84 \cdot 0^{c}$
$52 \cdot 4^{b}$
$5 \cdot 04$

$(\%)$

$44 \cdot \mathrm{I}^{a}$

$5 \mathrm{I} \cdot 6^{a b}$

$88 \cdot 4^{c}$

$37 \cdot 3^{a}$

$64 \cdot 3^{b}$

$65 \cdot 3^{b}$

$6 \cdot 17$

The difference between any two means of the stated factor which do not carry the same superscript is significant $(P<0.05)$.

* The availability is strictly 'apparent' because no estimate of the endogenous faecal excretion could be made. However, the term 'availability' is used in the text without the qualification.

Table 5. The calculated yields of available and retained fuoride from the original materials (expressed as parts available or retained fluoride per 100 parts of materials)

\begin{tabular}{|c|c|c|c|c|}
\hline & $\begin{array}{c}\text { F in sample } \\
(\%)\end{array}$ & $\begin{array}{c}\text { Availability } \\
\text { of fluoride } \\
(\%)\end{array}$ & $\begin{array}{c}\text { Yield of avail- } \\
\text { able fluoride } \\
\text { (parts/100 } \\
\text { parts of } \\
\text { original } \\
\text { material) }\end{array}$ & $\begin{array}{c}\text { Yield of } \\
\text { retained fluoride } \\
\text { (parts } / 100 \\
\text { parts of } \\
\text { original } \\
\text { material) }\end{array}$ \\
\hline Cryolite & $54 \cdot 0$ & $85 \cdot 0$ & $45 \cdot 9$ & 29.5 \\
\hline Sodium fluoride & $42 \cdot 5$ & $98 \cdot 0$ & $41 \cdot 7$ & $20 \cdot 0$ \\
\hline Aluminium fluoride & $57 \cdot 0$ & 15.9 & $9 \cdot I$ & $8 \cdot 0$ \\
\hline Mist eliminator grid solids & II 3 & $83 \cdot 4$ & $9 \cdot 4$ & $3 \cdot 5$ \\
\hline Reclaimed alumina & 0.53 & $52 \cdot 4$ & 0.28 & 0.18 \\
\hline
\end{tabular}

death; a post-mortem examination showed food to be blocking the trachea and it would appear that the animal choked to death.

Table 3 shows the mean amounts of fluoride ingested, excreted in the faeces and urine, the amounts apparently absorbed and the amounts retained. The basal diet group proved to have such a low intake of fluoride $(0.113 \mathrm{mg} / 7 \mathrm{~d})$ as to preclude any meaningful values for faeces and urine excretion being obtained and therefore this group of animals will be omitted from further discussion.

In view of the differences in the amounts of fluoride ingested, care must be taken in interpreting the results presented in Table 3 and therefore Table 4 presents values for the percent of intake which was absorbed (\% availability (strictly, this term should be 'apparent availability', as no measurement of endogenous faecal excretion has been made; however, the qualification will be omitted in the subsequent discussion)) and also the percent of that absorbed which was retained (\% retention); Fig. I shows the partition of ingested fluoride between the body, the faeces and the urine expressed as a percent of fluoride ingested.

It may be seen (Table 4) that the availability of the fluoride in $\mathrm{NaF}$, at both levels of ingestion was virtually $100 \%$ and that of the absorbed fluoride approximately $45-50 \%$ was retained in the body; most of the fluoride was excreted by way of the urine (see Table 3 and Fig. I).

It has generally been assumed that the fluoride availability of cryolite is considerably lower than that of NaF (Flatla, 1972). It is interesting, then, that the results here indicate a percentage availability as high as $85 \%$ for cryolite (Table 5). Moreover, the retention of 


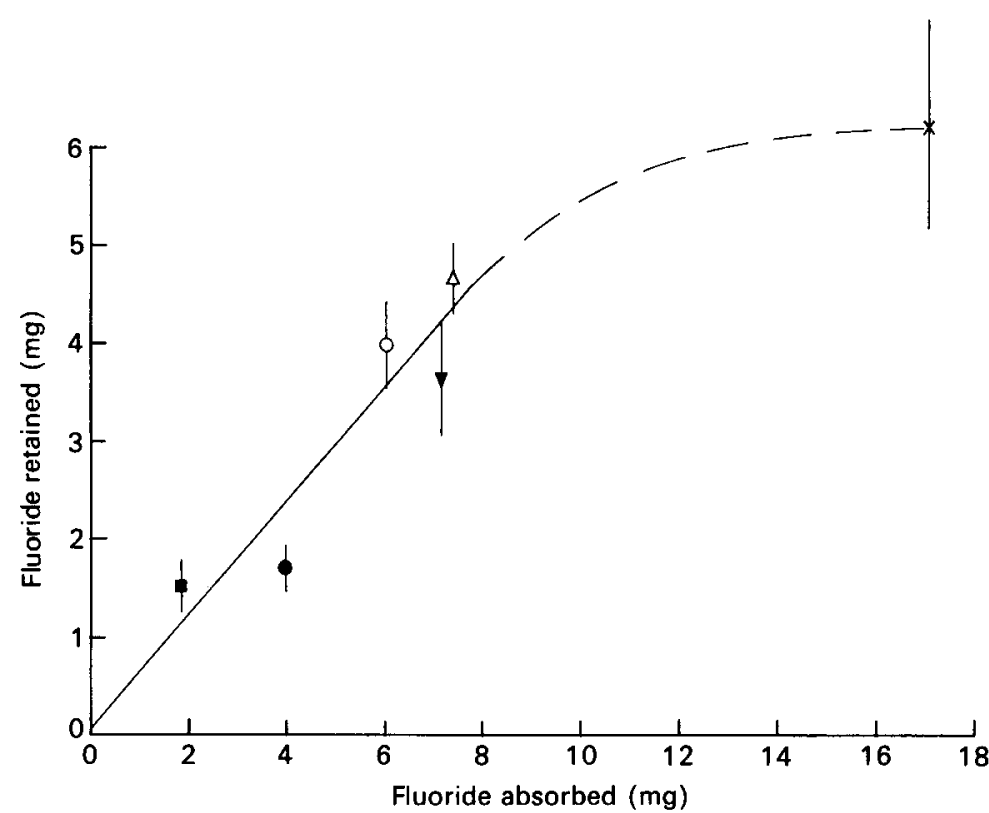

Fig. 2. The relationship between retained and absorbed fluoride. (Vertical lines indicate sE of the mean.) $\square, \mathrm{AlF}_{3} . \mathrm{H}_{2} \mathrm{O} ; \mathrm{O}, \mathrm{NaF}(7 \mathrm{I} \mathrm{gF} / \mathrm{kg}) ; \boldsymbol{\mathrm { N }}, \mathrm{NaF}(\mathrm{I} 35 \mathrm{gF} / \mathrm{kg}) ; \triangle$, cryolite; $\mathrm{O}$, reclaimed alumina; $\times$, mist eliminator grid solids. Straight line represents equation $y=0.586 x+0.07$, where $y$ is $\mathrm{mg} \mathrm{F}$ retained, $x$ is $\mathrm{mg} \mathrm{F}$ absorbed for all points except mist eliminator grid solids (see p. I44).

$64 \%$ of this (Table 4 ) causes the over-all yield of fluoride from cryolite to be even higher than that of $\mathrm{NaF}$. This has clear implications for livestock exposed to cryolite and demonstrates the weakness of using urine fluoride levels alone as a measure of comparative fluoride 'potential'. Although urine fluoride levels give a reasonable prediction of fluoride availability (Fig. $I$ and Table 5) differences in retention by bone tissue may be missed. This point is probably better illustrated by the MEG solids. In this case, although the percentage availability was high $(83.4 \%)$, and was reflected in a high urine fluoride concentration, only about one-third of the absorbed fluoride was retained. An interesting feature of this result is that, although detailed analyses of the compound were not available, a significant proportion of the fluoride-containing fraction was calcium fluoride. This is usually taken to be biologically inert with regard to fluoride availability, due to its low solubility. The high percentage availability shown here is therefore rather surprising. A repeated experiment using pure fluorspar $\left(\mathrm{CaF}_{2}\right)$ would therefore be of interest.

The percentage availability of the fluoride in the reclaimed alumina was much lower than that of the two sources referred to above while that in the $\mathrm{AlF}_{3} \cdot \mathrm{H}_{2} \mathrm{O}$ was very low indeed (see Table 4 ). It can also be seen from Table 4 that the proportion of the absorbed element retained from the reclaimed alumina $(65.3 \%)$ was not significantly different from that of the cryolite $(64.3 \%)$. It may also be seen (Table 4 ) that although little of the fluoride was absorbed from the $\mathrm{AlF}_{3} \cdot \mathrm{H}_{2} \mathrm{O}$ this was largely retained by the body.

In fact, when the values (Table 3 ) for the amounts of fluoride retained are plotted against the amounts of fluoride (see Fig. 2 ) there is a very highly significant correlation $(r 0.7 \mathrm{I}$, $P<0.001$ ) between these two factors. Fig. 2 shows a more or less linear relationship between the fluoride retained and that absorbed for all diets except for the MEG solids. In fact, if the values for this last-mentioned diet are omitted from the calculation, the correlation 


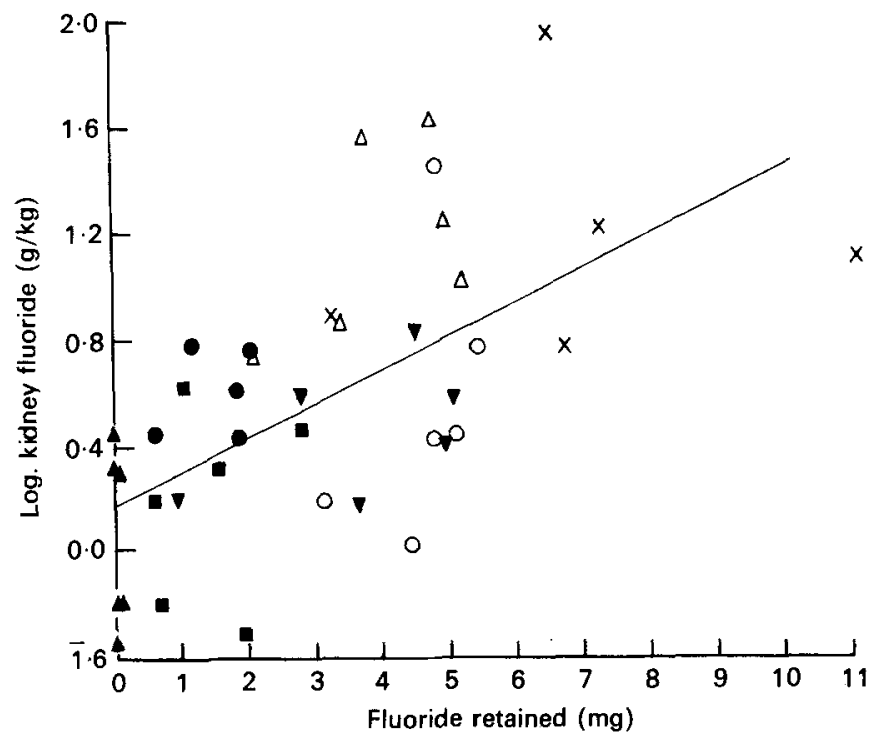

Fig. 3. The relationship between kidney fluoride concentration and total retained fluoride. $\Delta$, basal; $\mathrm{n}, \mathrm{AlF}_{3}, \mathrm{H}_{2} \mathrm{O} ; \mathrm{O}, \mathrm{NaF}$ (7Ig F/kg);, $\mathrm{NaF}$ ( $35 \mathrm{~g} \mathrm{~F} / \mathrm{kg}$ ); $\mathrm{O}$, cryolite; $\triangle$, reclaimed alumina; $x$, mist eliminator grid solids. Line represents the equation $y=0 \cdot 135 x+1 \cdot 185$, where $y=\log$ kidney $\mathrm{F}$ and $x=$ total retained $\mathrm{F}$ (mg); $r 0.65, P<0.01$.

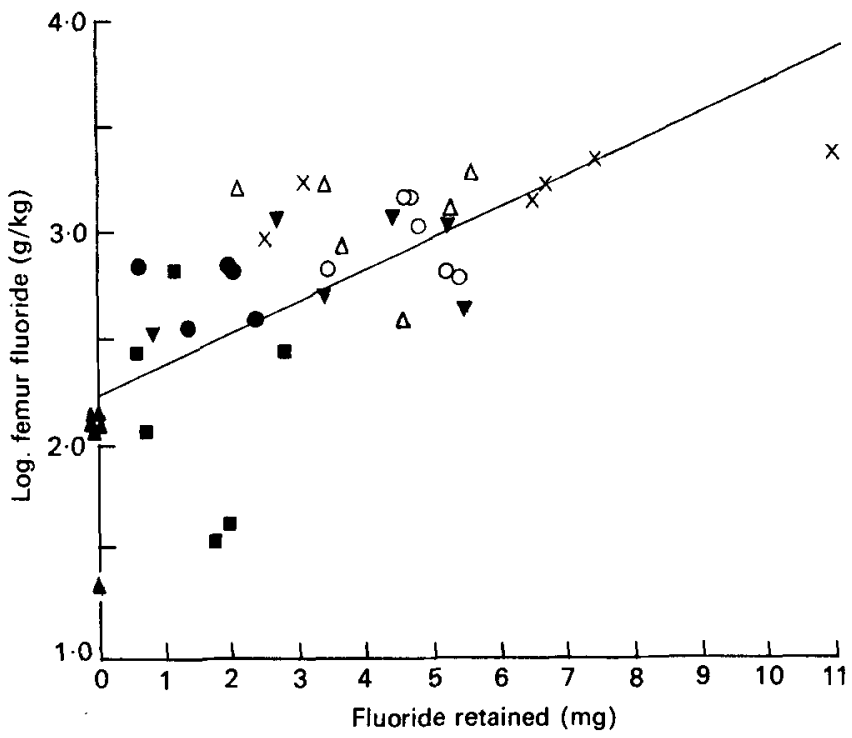

Fig. 4. The relationship between femur fuoride concentration and total retained fluoride. $\Delta$, basal; $\mathrm{a}, \mathrm{AiF}_{3} . \mathrm{H}_{2} \mathrm{O} ; \mathrm{NaF}(7 \mathrm{Ig} \mathrm{F} / \mathrm{kg}) ; \mathrm{V}, \mathrm{NaF}(135 \mathrm{~g} \mathrm{~F} / \mathrm{kg}) ; \mathrm{O}$, cryolite; $\triangle$, reclaimed alumina; $x$, mist eliminator grid solids. Line represents the equation $y=0.153 x+2.26$ where $y=\log$ femur $F$ and $x=$ total retained $F(\mathrm{mg}) . r 0.75, P<0.00 \mathrm{I}$. 
coefficient is even more highly significant $(r 0.806, P<0.001)$. The regression equation of the data excluding that from the MEG solids diet may be calculated as:

$$
y=0.586 x+0.07 \text {, }
$$

where $y$ is the amount of fluoride retained (mg) and $x$ is the amount of fluoride absorbed (mg).

This equation is plotted in Fig. 2, and as one would anticipate, the line almost passes through the origin. It would seem reasonable to conclude that up to a level of absorbed fluoride of approximately $8 \mathrm{mg} \mathrm{F} / 7 \mathrm{~d}$ (or about $\mathrm{I} \mathrm{mg} / \mathrm{d}$ ) for the present rats, approximately $60 \%$ of the absorbed $F$ is retained but that at higher levels of absorption this percentage retention decreases. It seems very probable that there is a finite limit to the amount of fluoride which can be retained by the rat.

In view of this fairly constant proportion of the absorbed fluoride which is retained, the relative toxicity of a particular material would appear to be best expressed in terms of the yield of available fluoride per 100 parts of the original material as is shown in Table 5. From this table it may be seen that every 100 parts of cryolite yields 45.9 parts of available fluoride and is clearly the most potentially dangerous of the five materials. Cryolite is, in fact, slightly more dangerous than sodium fluoride ( $4 \cdot 7$ parts) which is frequently used as a reference standard. MEG solids and $\mathrm{AlF}_{3} . \mathrm{H}_{2} \mathrm{O}$ yield $9 \cdot 4$ and $9 \cdot \mathrm{I}$ parts respectively from I00 parts of material, whilst I00 parts of reclaimed alumina yields only 0.3 parts of available fluoride. These figures may be further modified in the light of the retention/absorption characteristics of the compounds and yields of fluoride retained from each material are also given in Table 5. The above results, along with a knowledge of the relative amounts of each material produced by the plant, provide a basis on which to assess the relative importance of limiting the amounts of the various materials being discharged into the atmosphere.

Of the various tissues analysed for fluoride content only the kidney and femur showed any significant correlation with the amounts of fluoride absorbed or retained. Plots of log tissue $\mathrm{F}(\mathrm{g} / \mathrm{kg}$ dry matter basis) against the amount of fluoride retained by the body $(\mathrm{mg} \mathrm{F} / 7 \mathrm{~d}$ ) gave a correlation coefficient $(r)$ of $0.65(P<0.01)$ for the kidney (Fig. 3) and $r 0.75$ $(P<0.001)$ for the femur (Fig. 4$)$.

The excellent correlation found between the femur $F$ and that retained by the body is perhaps not surprising in view of the fact that the skeleton is the principal centre of deposition of absorbed fluoride. It is clear that at least within the range of fluoride intakes considered here, femur $F$ level would seem to offer a rapid alternative for the assessment of the amount of fluoride retained by the body. Aspects of bone retention of $F$ have been discussed by Suttie (1964, 1967), Suttie \& Phillips (1959), and others.

It is clearly unwise to extrapolate from these results directly to a field situation involving ruminant animals. Nevertheless, an assay such as this has the advantages of convenience and low expense and may give a great deal of information on, for example, the effectiveness and mode of action of fluoride alleviators, which would be particularly useful if used in conjunction with field observations.

The authors are grateful to Dr A. W. Davison, Department of Plant Biology, Newcastle University, for his continued support and assistance throughout this work. Thanks are also due to Alcan (UK) Ltd for the supply of materials and for financial support. 


\section{REFERENCES}

Burns, K. N. \& Allcroft, R. (1964). Fluorosis in cattle. I. Occurrence and effects in industrial areas of England and Wales, 1954-57. Animal disease surveys report no. 2, part I. London: HM Stationery Office.

Cernik, A. A., Cooke, J. A. \& Hall, R. J. (1970). Nature, Lond. 227, I 260.

Cooke, J. A., Johnson, M. S., Davison, A. W. \& Bradshaw, A. D. (1976). Envir. Pollut. Ir, 9.

Duncan, D. B. (1955). Biometrics II, I.

Flatla, J. L. (1972). The fuorine problem in practice-poisoning in ruminants. Festskrift til $\mathrm{K}$. Breirem 70 ars dag - 2oth Apr. 1972) redaksjonskomite, Oslo.

National Academy of Sciences (1971). Biological effects of atmospheric pollutants; fluorides [J. J. Vostal, editor]. Washington: National Academy of Sciences.

Shupe, J. L. (1970). Am. ind. Hyg. Ass. J. 31, 240.

Steel, R. G. D. \& Torrie, J. H. (1960). Principles and Procedures of Statistics. New York: McGraw-Hill.

Suttie, J. W. (1964). J. Air Pollut. Control Ass. 14, 461.

Suttie, J. W. (1967). Am. J. vet. Res. 28, 709.

Suttie, J. W. (1969). Air Quality Criteria to Protect Livestock from Fluoride Toxicity. New York: The Aluminium Association.

Suttie, J. W., Carlson, J. R. \& Faltin, E. C. (1972). J. Dairy Sci. 55, 790.

Suttie, J. W. \& Phillips, P. H. (I 959). Archs Biochem. Biophys. 83, 355.

Suttie, J. W., Phillips, P. H. \& Miller, R. F. (1958). J. Nutr. 65, 293.

Thompson, A. (1970). J. Inst. Anim. Technol. 21, 15.

Wright, D. A. \& Davison, A. W. (1975). Envir. Pollut. 8, I. 